\title{
BEECH LEAVES BRIQUETTES AS FUEL FOR A HOME COMBUSTION UNIT
}

\author{
JIŘÍ RYŠAVÝ, JIŘÍ HORÁK, LENKA KUBOŇOVÁ, MIROSLAV JAROCH, FRANTIŠEK HOPAN, \\ KAMIL KRPEC \& PETR KUBESA \\ VSB - Technical University of Ostrava, Energy Research Center, Czech Republic
}

\begin{abstract}
This study is aimed at the possibility of the fallen (waste) beech leaves usage as material for briquettes production. The main purpose of beech leaves briquetting in this study is the possibility of using it in small home combustion units, as partial substitute of wood. From the briquetting point of view, it is necessary to dry the leaves to approximately $15 \%$ of water content (it takes more than a month by free (natural) drying in an approximately $10 \mathrm{~cm}$ high layer inside a heated room). Beech leaves briquetting by automatic press is an easy process, but with diverse lengths of briquettes at the output $(2-20 \mathrm{~cm})$. Proximate and ultimate analyses of collected beech leaves were done. A briquette sample was subjected to thermogravimetric analysis, which shows the temperature ranges of drying and hemicellulose, cellulose and lignin decomposition. The determined temperature ranges correspond to those from other literature sources. Combustion tests proved the possibility of beech leaves briquettes usage as fuel in a small combustion unit. All limit values of the actual European standard EN 13240:2001 were met and some limit values of future European Standard Commission regulation (EU) 2015/1185 were met as well. Results of energy efficiency and mass concentrations of pollutants in the flue gas will differ with different stove and different stove settings. Due to the properties of the beech leaves briquettes (high mass fraction of ash and fast disintegration on the grate during the combustion process), it is appropriate, especially for long term use, to combine this kind of fuel with a conventional one.

Keywords: tree leaves, briquetting, biomass, renewable energy, solid fuel.
\end{abstract}

\section{INTRODUCTION}

Numerous towns worldwide are trying to increase the living standards by maintenance and modernization of public places. At the same time, many of them try to be as "green" as possible, which leads to a situation when a lot of public places are full of grass and trees. These steps are undoubtedly beneficial for people visiting those places. For the town itself, each tree and grass means some worries with grass cutting and leaves collecting in autumn as well. Both products of greenery maintenance become waste immediately after cutting and collecting (according to Czech Act no. 185/2001 [1]) and towns have to treat them as waste. Currently the most widespread way in Czech Republic is composting of bio waste, following sale of compost and substrate back to the people.

At the same time, there are approximately 500 thousand houses in the Czech Republic, which are heated by combustion of solid fuels (wood logs, briquettes, pellets and coal) in boilers, or stoves. These kinds of fuels are often transported over long distance, which increases their cost and also the carbon footprint of these fuels [2].

In recent years, the amount of burned briquettes has been increasing. Some reasons for this fact could be: i) there is no need to additionally dry the fuel for a year or more in case of briquettes; ii) their energy density is high, so a smaller storage space is required; iii) it is possible to burn the briquettes in stoves and boilers as well. Their production is limited by the capacity of sawmills and by the amount of sawdust which they produce [3].

From an energy point of view, greenery, especially fallen leaves, is considered relatively homogeneous biomass suitable for further use (for example briquetting). Briquetting of fallen 
leaves could simplify the situation of waste management in towns and can consequently ensure a source of clean energy for heating households by solid fuels.

The potential of different kinds of leaves briquettes was observed before in recent research works of Deepak et al. [4] (areca leaves), Khorasgani et al. [5] (oak leaves), Anggono et al. [6] (amboyna wood leaves), Biswas [7] (sugar cane leaves), Hardianto et al. [8] (amboyna pine leaves), Shiferaw et al. [9] (eucalyptus globulus leaves residues), Ushakov et al. [10] (black poplar leaves), Shuma et al. [11] (mopani leaves and sugar cane leaves), Malak et al. [12] (willow leaves) and Jittabut [13] (sugarcane leaves). In the mentioned research papers, ultimate and proximate analyses of different types of leaves were made, as well as investigations on the dependence of calorific value on carbonization temperature, physical properties and ignition temperature.

A previous study of Nurdin et al. [14] describes the possibilities of tibarau sugar cane bio-briquettes usage. The biggest net calorific value $(32,270 \mathrm{~kJ} / \mathrm{kg})$ was reached after the carbonization at the temperature $300^{\circ} \mathrm{C}$, thereby an alternative charcoal was produced.

The results of all research suggest the possibility of real use of briquettes in power engineering.

This study is aimed to determine the possibilities of further use of fallen beech leaves by their briquetting and their subsequent combustion in small stoves to heat households.

\section{MATERIALS AND METHODS}

For the experimental part of this research, own beech leaves briquettes were made. The process of their production with all details is described below.

For collecting the beech leaves, the area of urban forest known as Bělský les on the edge of Ostrava town was chosen. Bělský les is a mixed forest with few types of broad-leaved trees (beech, oak, birch). A collecting place with only beech trees was chosen for this research. The weather on the day of leaves collection can significantly affect mass fraction of water in the leaves, so an average autumn day (temperature around $9^{\circ} \mathrm{C}$, cloudy - without rain, day after light rain) was chosen. Approximately $70 \mathrm{~kg}$ of beech leaves was collected. This material was transported to the Energy Research Center, Ostrava. Immediately after the transport, analysis of water mass fraction was done (by HR 73 Halogen Moisture analyzer). During the next month, free (natural) drying in the laboratory followed. Leaves were manually aerated and the water mass fraction in the leaves was measured every few days. The leaves were stored on the sail in a layer of approximately $10 \mathrm{~cm}$. The process of changes in water mass fraction in the leaves during the first month of drying is shown in Table 1. The storage place is shown in the Fig. 1.

Table 1: Process of water mass fraction changes in the leaves before crushing.

\begin{tabular}{|c|c|c|c|}
\hline $\begin{array}{c}\text { Days after } \\
\text { collection }\end{array}$ & $\begin{array}{c}\text { Mass fraction of water } \\
\text { in the leaves (\%) }\end{array}$ & Days after collection & $\begin{array}{c}\text { Mass fraction of water } \\
\text { in the leaves (\%) }\end{array}$ \\
\hline 0 & 66.9 & 9 & 41.1 \\
\hline 2 & 58.8 & 10 & 40.4 \\
\hline 3 & 50.3 & 16 & 36.4 \\
\hline 7 & 43.9 & 22 & 30.6 \\
\hline 8 & 42.5 & 27 & 27.1 \\
\hline
\end{tabular}




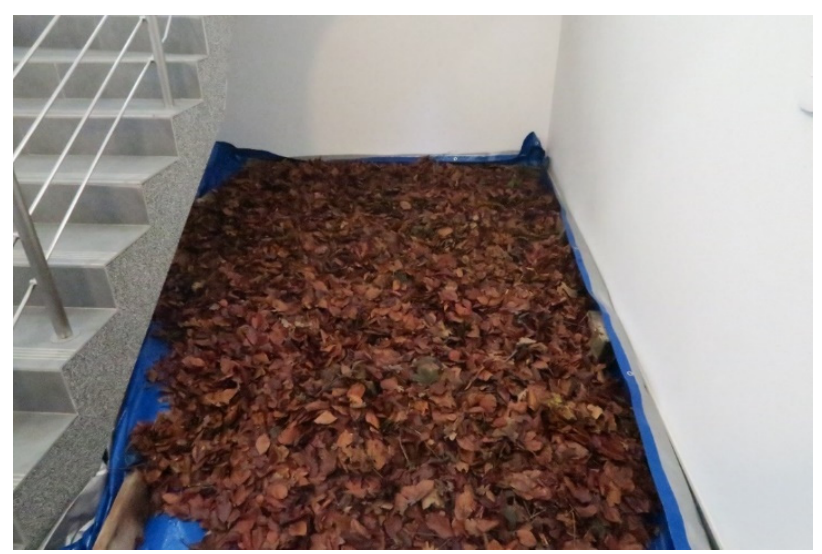

Figure 1: Storage place of leaves during spontaneous drying in Energy Research Center, Ostrava.

After 27 days of drying, the leaves were crushed. For this process, a hammering crusher was used. At the crusher outlet, a sieve with a sieve opening of $20 \mathrm{~mm}$ was placed. The dimension of the sieve was chosen according to previous experiences with this material. Crushing took place after drying because leaves with high water mass fraction clogged the sieve which was experimentally determined. Crushed leaves were stored at the same place as before for a two-week period after-drying. The final water mass fraction in the leaves was $14.8 \%$ before briquetting. The recommended water mass fraction in the material according to briquette machine producer was the reason for after-drying.

For the briquetting, the pressing equipment Dinamic $70 \mathrm{~N}$ was used (Fig. 2). This equipment was originally designed for wood residues (especially saw dust) briquetting. The final product of the equipment are cylinders with a diameter of $55 \mathrm{~mm}$. The length of the briquettes is different according to the type of processed material. An example of beech leaves briquette is shown in Fig. 3 .

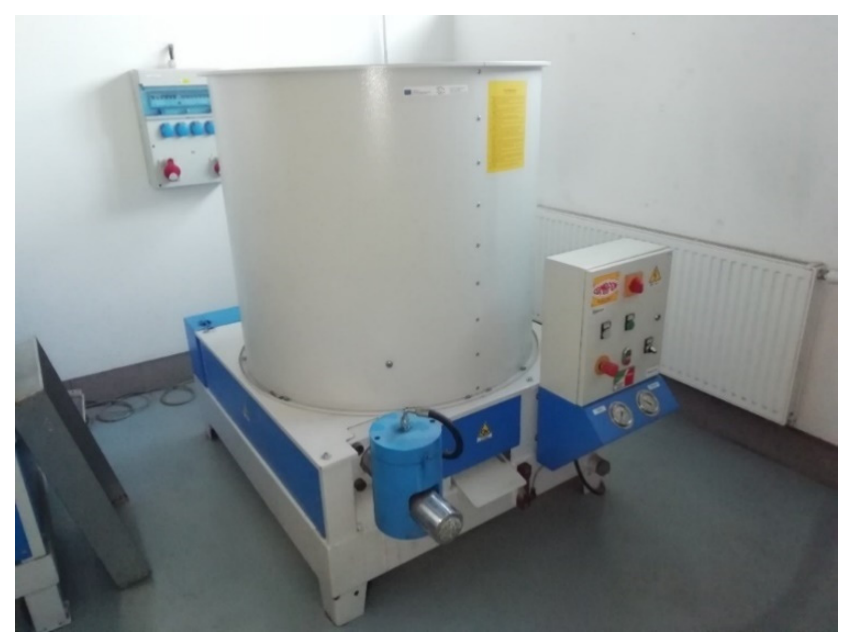

Figure 2: Used briquetting press Dinamic 70N. 


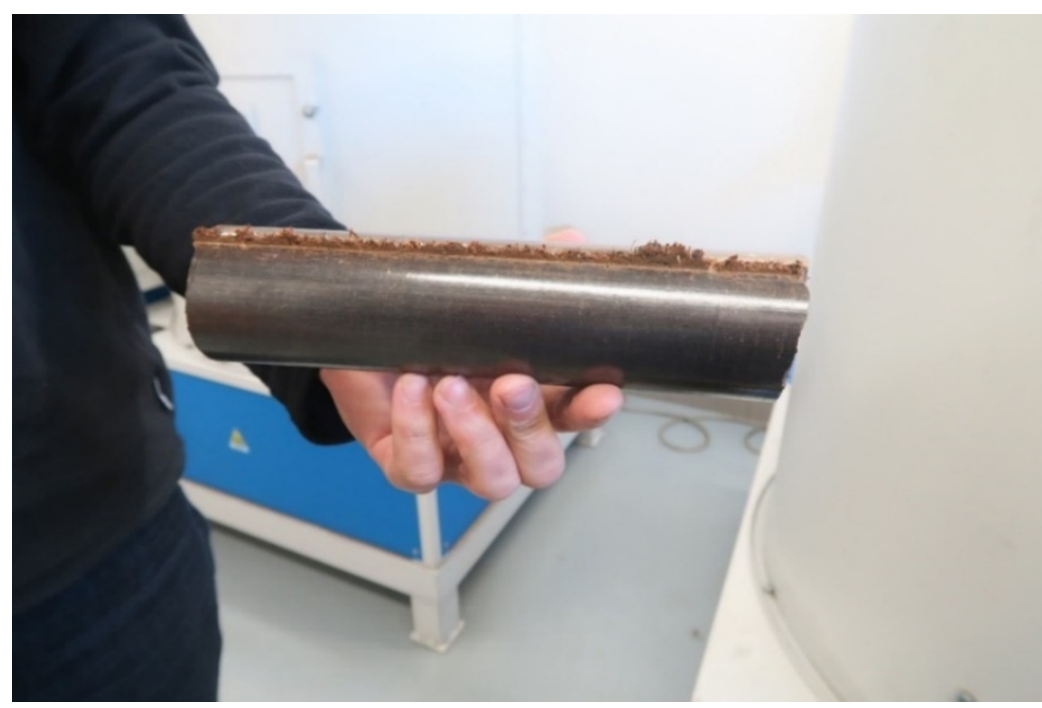

Figure 3: The final product - beech leaves briquette.

During pressing, the material was slightly heated by compression, thereby partially dried. The machine worked with the described material without any problems and there was no clogging. The produced briquettes have variable length, from 2 to $20 \mathrm{~cm}$. Any significant crumbling did not occur during their manipulation.

\subsection{Proximate and ultimate analyses}

Proximate and ultimate analyses of leaves were done after their collection. The results of these analyses are shown in Table 2 with recalculations of states before and after briquetting. For comparison, the standard briquette analysis (with ÖNORM certification; without bark) is included in the table.

Table 2: Results of proximate and ultimate analyses of beech leaves in different states.

\begin{tabular}{|l|c|c|c|c|c|}
\hline Element & Unit & $\begin{array}{c}\text { Raw } \\
\text { state }\end{array}$ & $\begin{array}{c}\text { Before } \\
\text { briquetting }\end{array}$ & $\begin{array}{c}\text { Aftandard } \\
\text { Ariquetting } \\
\text { briquettes with } \\
\text { ONORM } \\
\text { certification }\end{array}$ \\
\hline Carbon (C) & $(\%)$ & 15.93 & 39.80 & 42.56 & 46.43 \\
\hline Hydrogen (H) & $(\%)$ & 1.73 & 4.32 & 4.62 & 5.66 \\
\hline Nitrogen (N) & $(\%)$ & 0.27 & 0.68 & 0.73 & 0.30 \\
\hline Oxygen (O) & $(\%)$ & 11.33 & 28.29 & 30.25 & 38.09 \\
\hline Sulfur (S) & $(\%)$ & 0.03 & 0.08 & 0.09 & 0 \\
\hline Water (W) & $(\%)$ & 65.88 & 14.77 & 8.87 & 9.21 \\
\hline Ash (A) & $(\%)$ & 4.32 & 12.05 & 12.88 & 0.31 \\
\hline $\begin{array}{l}\text { Net calorific } \\
\text { value (Qi) }\end{array}$ & $(\mathrm{MJ} / \mathrm{kg})$ & 4.32 & 14.47 & 15.64 & 17.03 \\
\hline
\end{tabular}


The high water mass fraction at the day of leaves collecting is evident. Also the high ash mass fraction of the briquettes is evident. For comparison, there is approximately 43 times less ash in analyzed standard wooden briquettes than in beech leaves briquettes. Other differences include lower mass fractions of oxygen, carbon and hydrogen and higher mass fraction of nitrogen and sulfur in the beech leaves briquettes. From net calorific value point of view, the briquettes from beech leaves have approximately $8 \%$ less energy per one kilogram than the standard wooden briquettes.

\subsection{Thermal gravimetric analysis (TGA)}

Biomass is composed of three major components which are: cellulose, hemicellulose, and lignin with traces of minerals and extractives [15]. Generally, the mass fractions of cellulose, hemicellulose, and lignin in biomass are in the range of 20-35 wt $\%, 40-45 \mathrm{wt} \%$, and $15-30$ $\mathrm{wt} \%$, respectively [16]. The proportion of these components depends on the type of biomass. The different temperature ranges of their decomposition according to different types of biomass as well as the heating rate $\left({ }^{\circ} \mathrm{C} / \mathrm{min}\right)$ and the gas flow $(\mathrm{ml} / \mathrm{min})$ are summarized in Table 3, under TG conditions where RT stands for room temperature.

Table 3: Temperature ranges of thermal decomposition of hemicellulose, cellulose and lignin.

\begin{tabular}{|c|c|c|c|c|c|}
\hline $\begin{array}{c}\text { Hemicellulose } \\
\left({ }^{\circ} \mathrm{C}\right)\end{array}$ & $\begin{array}{c}\text { Cellulose } \\
\left({ }^{\circ} \mathrm{C}\right)\end{array}$ & $\begin{array}{c}\text { Lignin } \\
\left({ }^{\circ} \mathrm{C}\right)\end{array}$ & $\begin{array}{c}\text { Type of } \\
\text { biomass }\end{array}$ & TG conditions & Ref. \\
\hline $180-285$ & $250-360$ & $350-600$ & $\begin{array}{c}\text { Prosopis } \\
\text { juliflora }\end{array}$ & $\begin{array}{c}30-600^{\circ} \mathrm{C} ; 2,5,10,15,20, \\
25^{\circ} \mathrm{C} / \mathrm{min} ; 60 \mathrm{ml} / \mathrm{min} \text { of } \mathrm{Ar} ; \\
\text { isotherm at } 105^{\circ} \mathrm{C} \text { for } 20 \mathrm{~min} \\
\text { for moisture removal). }\end{array}$ & {$[19]$} \\
\hline $250-400^{\mathrm{a}}$ & $250-400^{\mathrm{a}}$ & $400-700$ & Pine wood & $\begin{array}{c}\mathrm{RT}-1000^{\circ} \mathrm{C} ; 10,20,30, \\
40^{\circ} \mathrm{C} / \mathrm{min} ; 60 \mathrm{ml} / \mathrm{min} \text { of } 2, \\
\text { isotherm at } 1,000^{\circ} \mathrm{C} \text { in the flow } \\
5 \mathrm{ml} / \mathrm{min} \text { of an excess } \mathrm{O}_{2} .\end{array}$ & {$[20]$} \\
\hline $300-400^{\mathrm{a}}$ & $300-400^{\mathrm{a}}$ & $400-520$ & $\begin{array}{c}\text { Platanus } \\
\text { Orientalis } \\
\text { leaves }\end{array}$ & $\begin{array}{c}30-700^{\circ} \mathrm{C} ; 10^{\circ} \mathrm{C} / \mathrm{min}, 50 \mathrm{ml} / \mathrm{min} \\
\text { of air }\left(\mathrm{N}_{2} 79 \%, \mathrm{O}_{2} 21 \%\right) .\end{array}$ & {$[21]$} \\
\hline $180-370$ & $290-400$ & $200-580$ & $\begin{array}{c}\text { Biomass } \\
\text { components }\end{array}$ & $\begin{array}{c}\mathrm{RT}-800^{\circ} \mathrm{C} ; 20^{\circ} \mathrm{C} ; 40 \mathrm{ml} / \mathrm{min} \\
\text { of } \mathrm{N}_{2} .\end{array}$ & {$[22]$} \\
\hline $172-466^{\mathrm{a}}$ & $172-466^{\mathrm{a}}$ & $466-792$ & $\begin{array}{c}\text { Casuarina } \\
\text { leaves }\end{array}$ & $\begin{array}{c}\mathrm{RT}-800^{\circ} \mathrm{C} ; 10^{\circ} \mathrm{C} / \mathrm{min} ; \\
100 \mathrm{ml} / \mathrm{min} \text { of } \mathrm{N}_{2} .\end{array}$ & {$[18]$} \\
\hline $180-360$ & $360-500$ & $500-700$ & Olive leaves & $\begin{array}{r}30-1,000^{\circ} \mathrm{C} ; 10^{\circ} \mathrm{C} / \mathrm{min} ; \\
60 \mathrm{ml} / \mathrm{min} \text { of air. }\end{array}$ & {$[23]$} \\
\hline
\end{tabular}

${ }^{\text {a }}$ The TG peaks of hemicellulose and cellulose overlapped in this pyrolysis zone.

Thermochemical methods include pyrolysis, gasification, liquefaction, torrefaction, and combustion [17]. As presented by Parathasarathy and Narayanan [18], thermal decomposition of biomass in inert atmosphere can be divided in three zones: zone I refers to the evolution of moisture, zone II is refers to the degradation of hemicellulose-cellulose components and zone III corresponds to the decomposition of lignin and inorganics.

The temperature of moisture removal depends on type of biomass and the amount of moisture. Above a temperature of $200^{\circ} \mathrm{C}$ there is a thermal decomposition of organic components (cleavage of glycoside bonds). Hemicellulose is the first polysaccharide which is decomposed. As hemicellulose and cellulose often degrade at a very close temperature range, their degradation zones often overlap with each other [18]. 
At temperatures above $400^{\circ} \mathrm{C}$, the pyrolysis process gets enhanced to form a solid residue (charcoal) and the volatile content comes down quite dramatically. The zone after which there is no further weight loss is called the passive zone, i.e., devolatilization does not occur above these temperatures, yet carbon and ash are formed as the final solid residue [19], [24]. The third stage $\left(600-800^{\circ} \mathrm{C}\right)$ is also assigned to removal and reaction of inorganic matter and beyond $800^{\circ} \mathrm{C}$, transformation of residual inorganic matter occurs [25].

\subsection{Combustion test}

Combustion tests were performed to determine the behavior of beech leaves briquettes during their real combustion in a small scale stove.

A Storch ESTELLI KERAMIK stove was chosen as the combustion unit. It is a fireplace stove originally designed for wood log combustion. This stove is designed without any heat exchanger or forced airflow by a fan. The heat is removed only through the walls of the device and through a flue gas duct wall to the surroundings of the device. The flue gases pass through a combustion chamber (with a rotary grate) and then into the flue gas path. This stove was chosen for its easy operation and very controllable combustion air inlet. Presumed heat output is $7 \mathrm{~kW}$. Ignition was performed by beech log wood. After the creation of an ardent embers basic layer, the first batch of beech leaves briquettes was added. Seven batches of beech leaves briquettes were used in total during the combustion test.

\section{RESULTS AND DISCUSSION}

\subsection{Thermogravimetric analysis evaluation}

Thermogravimetric analysis of beech leaves briquettes was performed on the instrument STA $441 \mathrm{~F} 1$ Jupiter (Netzsch). The initial mass of the beech leaves sample was $52.3 \mathrm{mg}$. The heating rate was $10^{\circ} \mathrm{C} / \mathrm{min}$ from RT to $1,500^{\circ} \mathrm{C}$ in $100 \mathrm{ml} / \mathrm{min}$ of $\mathrm{N}_{2}$. The graph of beech leaves thermal decomposition is shown in Fig. 4.

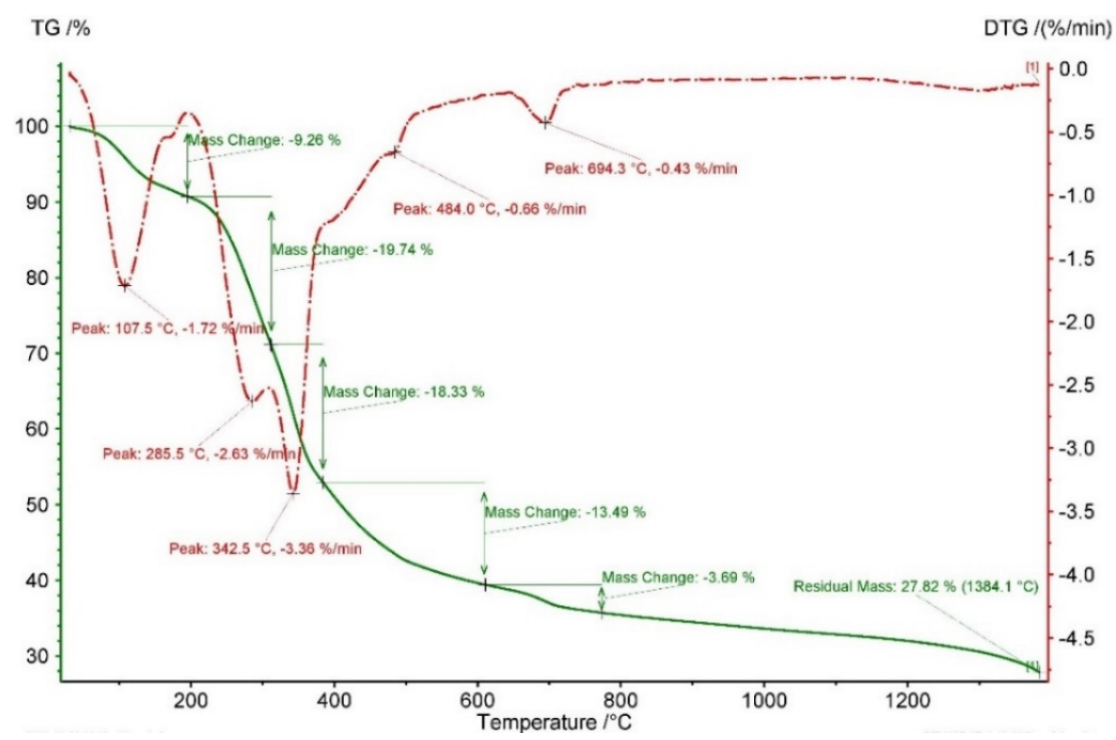

Figure 4: Graph of thermal decomposition of beech leaves. 
Measured values of individual beech leaves briquettes decomposition temperatures compared with those mentioned in the literature are given below.

- Zone I: temperature range $30-195^{\circ} \mathrm{C}$ (moisture removal) consistent with that in literature sources [20], [22], [23].

- Zone II: temperature ranges $195-310^{\circ} \mathrm{C}$ and $310-380^{\circ} \mathrm{C}$ (hemicellulose and cellulose decomposition, respectively) especially corresponds with those of literature sources [1], [20], [22] where the decomposition of hemicellulose was not overlapped with cellulose decomposition.

- Zone III: temperature range $380-610^{\circ} \mathrm{C}$ (lignin decomposition) corresponds with that of literature sources [1], [20], [21] according to the starting temperature of decomposition. Temperature range $610-770^{\circ} \mathrm{C}$ corresponds with the removal of inorganic matter [22].

- Residual mass of the beach leaves sample at the temperature $1,384^{\circ} \mathrm{C}$ was $27.8 \%$.

\subsection{Combustion tests evaluation}

The final (presented) values of mass concentrations of pollutants were recalculated to normal conditions $(T=273.15 \mathrm{~K} ; \mathrm{p}=101,325 \mathrm{~Pa})$ and a reference volume fraction of oxygen in the flue gas $\left(\varphi_{\text {ref; }[02]}=13 \%\right)$. There are limits for flue gas composition according to national standards and according to Commission regulation (EU) 2015/1185, which will apply from 1 January 2022.

According to the standard EN 13240:2001 [26] mentioned above (currently in effect), there is a limit only for mass concentration of CO $\left(12,500 \mathrm{mg} / \mathrm{m}^{3}\right)$. There is also minimum efficiency limit (50\%). According to this standard, all tests were in accordance with the standard. The final values of this research are not compared with other national laws currently in effect in other states.

Further evaluation will be related to Commission regulation (EU) $2015 / 1185$ because it is stricter. There are mass concentration limits for CO $\left(1,500 \mathrm{mg} / \mathrm{m}^{3}\right)$, OGC $\left(120 \mathrm{mg} / \mathrm{m}^{3}\right), \mathrm{NO}_{\mathrm{x}}$ $\left(200 \mathrm{mg} / \mathrm{m}^{3}\right)$ and PM $\left(40 \mathrm{mg} / \mathrm{m}^{3}\right)$. The limit for seasonal space heating energy efficiency is $65 \%$ [27].

As can be seen in Table 4, the heat output usually ranged between 5.2 to $6.3 \mathrm{~kW}$ with one anomaly $(8.1 \mathrm{~kW})$. The energy efficiency ranged between $67.7 \%$ and $74.3 \%$ (recalculation to seasonal energy efficiency decreased these values by $10 \%$ for this kind of stove) because of relatively high temperature of flue gas at the stove outlet. $\mathrm{CO}$ mass concentration limits were met during 5 of 7 tests. OGC mass concentration limits were met during 5 of 7 tests. NOx limits were not met during all the tests. Mass concentration of PM in the flue gas was not observed during the tests.

During the combustion process, the briquettes showed a higher tendency to be incohesive; they disintegrated earlier than the standard wood briquettes.

\subsection{Energy and monetary costs of production}

The cost of leaves briquettes production may vary according to several factors. The first factor is the collection process, where the type of terrain, the type of trees, their density and used method dramatically change the cost of leaves collecting. The most expensive part of leaves collecting, especially in the EU, is the price of human labor.

The second factor is transport. There lies the main advantage of this type of fuel, because it is formed in a town and in the same town it can be used. No matter what happens with the 
Table 4: Combustion tests results: green color symbolizes fulfilled values according to Commission regulation (EU) 2015/1185; red color symbolizes unfulfilled values according to Commission regulation (EU) 2015/1185.

\begin{tabular}{|l|c|c|c|c|c|c|c|c|c|}
\hline Mode number & & & 1 & 2 & 3 & 4 & 5 & 6 & 7 \\
\hline Test time & $\mathrm{h}$ & 0.8 & 0.7 & 0.9 & 0.6 & 0.7 & 0.7 & 0.8 & \\
\hline $\begin{array}{l}\text { Average heat output during the } \\
\text { mode }\end{array}$ & $\mathrm{kW}$ & 6.0 & 6.3 & 5.2 & 8.1 & 6.2 & 6.0 & 5.4 & \\
\hline Fuel consumption & $\mathrm{kg} / \mathrm{h}$ & 2.1 & 2.1 & 1.8 & 2.8 & 2.2 & 2.2 & 2.0 & \\
\hline Power input & & $\mathrm{kW}$ & 8.3 & 8.5 & 7.2 & 11.3 & 8.7 & 8.7 & 8.0 \\
\hline $\begin{array}{l}\text { Seasonal space heating energy } \\
\text { efficiency }\end{array}$ & & $\%$ & 62.0 & 64.3 & 62.7 & 61.7 & 61.5 & 59.0 & 57.7 \\
\hline Flue gas temperature & & ${ }^{\circ} \mathrm{C}$ & 338 & 321 & 304 & 318 & 304 & 279 & 282 \\
\hline $\begin{array}{l}\text { Volume fraction of oxygen in } \\
\text { the flue gas }\end{array}$ & & $\%$ & 10.8 & 10.0 & 11.0 & 11.1 & 11.1 & 12.2 & 12.0 \\
\hline Air excess ratio & & - & 2.07 & 1.92 & 2.11 & 2.13 & 2.11 & 2.40 & 2.32 \\
\hline $\begin{array}{l}\text { Reference oxygen volume } \\
\text { fraction }\end{array}$ & & $\%{ }_{\mathrm{vol}}$ & 13 & 13 & 13 & 13 & 13 & 13 & 13 \\
\hline $\begin{array}{l}\text { Mass concentration of } \\
\text { pollutants in the flue gas } \\
\text { (recalculated to reference } \\
\text { oxygen volume fraction } 13 \%)\end{array}$ & $\mathrm{CO}$ & $\mathrm{mg} / \mathrm{m}^{3}$ & 1,50 & 1,08 & 1,51 & 1,43 & 1,08 & 1,40 & 1,37 \\
\cline { 2 - 10 } & $\mathrm{NO}_{\mathrm{x}}$ & $\mathrm{mg} / \mathrm{m}^{3}$ & 267 & 281 & 277 & 321 & 339 & 378 & 356 \\
\cline { 2 - 10 } & $\mathrm{OGC}_{2}$ & $\mathrm{mg} / \mathrm{m}^{3}$ & 38 & 32 & 98 & 92 & 97 & 228 & 256 \\
\hline & $\mathrm{CO}_{2}$ & $\mathrm{~g} / \mathrm{m}^{3}$ & 148 & 148 & 148 & 147 & 148 & 146 & 146 \\
\hline
\end{tabular}

Note: Final mass concentration of $\mathrm{NO}_{\mathrm{x}}$ is recalculated to $\mathrm{NO}_{2}$.

bio-waste (leaves) next, it is necessary to maintain the green areas in the towns, so collecting and transport costs can be neglected from the overall perspective of briquette preparation.

The third factor is the drying process, which depends on the manner of leaves drying. They can be dried naturally or technologically. If they are spontaneously dried, a large roofed and ventilated space is required. In this case the only requirement is regular rummaging of the leaves layer. No additional energy is needed. If they are dried technologically in some continuously dried room, drying speed towards desired mass fraction of water is many times faster. In that case the energy consumption to dry the leaves from the raw mass fraction of water $(65 \%)$ to the briquetting mass fraction of water $(15 \%)$ per $\mathrm{kg}$ of briquettes is approximately 3.7 MJ of heat energy (calculated by latent evaporating heat of water). This is approximately $24 \%$ of the total chemically bound energy in briquettes. Collection of dryer leaves could significantly decrease the energy consumption.

The fourth factor is the briquetting itself. There are many briquetting presses available. Many of them allow the pressing of briquettes from different type of materials, such as leaves. Their cost ranges between 1,000 and 20,000 $€$ according to the mass flow of the briquettes at the output. The energy consumption of this process is approximately $0.36 \mathrm{MJ}$ of electrical energy per $\mathrm{kg}$ of briquettes which is approximately $2.3 \%$ of the total chemically bound energy in briquettes.

\section{CONCLUSIONS}

Beech leaves were collected, spontaneously dried, crushed and pressed into briquettes. These briquettes were dark, with standard shape and variable length. The beech leaves briquettes were analyzed and, in comparison with standard wooden ones (with ÖNORM certification), were found to exhibit a higher mass fraction of ash and lower net calorific value. By 
thermogravimetric analysis, the temperature ranges of hemicellulose, cellulose and lignin decomposition were described.

A few years old, regularly used stove (Storch ESTELLI KERAMIK) met the actual legislative limits during combustion tests with this kind of fuel.

The leaves briquettes preparation could consume from approximately $2.3 \%$ to $26.4 \%$ of the total chemically bound energy in briquettes according to the type of their drying process.

\section{ACKNOWLEDGEMENTS}

This article was prepared within the OP RDE project "Research on the identification of combustion of unsuitable fuels and systems of self-diagnostics of boilers combusting solid fuels for domestic heating", identification code CZ.02.1.01/0.0/0.0/18 069/0010049, with the financial support from the European Regional Development Fund. This article was also prepared within the project SP2020/80 "Determination of catalysts influence on flue gas composition from small scale combustion equipment and possibilities of elimination of periodical curve of bio-fireplaces heat output" and in the framework of the grant program "Support for Science and Research in the Moravia-Silesia Region 2018", (RRC/10/2018), financed from the budget of the Moravian-Silesian Region.

\section{REFERENCES}

[1] Czech act no. 185/2001, Coll Act on Waste and on Amendment of Some Other Acts.

[2] Czech Hydrometeorological Institute, Czech Republic Emission Balance. http://portal.chmi.cz/files/portal/docs/uoco/oez/embil/dokumentySpolecne.html. Accessed on: 4 Jan. 2020.

[3] Česká peleta, Czech pellet: healthy, comfort fuel z.s.p.o. https://www.ceska-peleta.cz/. Accessed on: 4 Jan. 2020.

[4] Deepak, K.B., Manujesh, B.J., Vivek, A. \& Yashas, B.K., Development and study of fuel briquettes from areca leaves: A potential renewable energy source. AIP Conference Proceedings 2080, 2019. https://doi.org/10.1063/1.5092907.

[5] Khorasgani, N.B., Sengul, A.B. \& Asmatulu, E., Briquetting grass and tree leaf biomass for sustainable production of future fuels: A potential renewable energy source. Biomass Conversion and Biorefinery, 2019. https://doi.org/10.1007/s13399019-00465-7.

[6] Anggono, W., Suprianto, F.D., Gotama, G.J., Sutrisno, A. \& Evander, J., Combustion characteristics behavior of Pterocarpus indicus leaves waste briquette at various particle size and pressure. IOP Conference Series: Materials Science and Engineering, vol. 417, 2018. https://doi.org/10.1088/1757-899X/417/1/012007.

[7] Biswas, D.P., Physicochemical property and heating value analyses of charcoal briquettes from agricultural wastes: An alternative renewable energy source. International Conference on Computer, Communication, Chemical, Material and Electronic Engineering (IC4ME2), IEEE, pp. 1-5, 2018. https://doi.org/10.1109/ IC4ME2.2018.8465639.

[8] Hardianto, T., Pambudi, F.F. \& Irhamna, A.R., A study on lignin characteristic as internal binder in hot briquetting process of organic municipal solid waste. AIP Conference Proceedings, 1984, 2018. https://doi.org/10.1063/1.5046634.

[9] Shiferaw, Y. et al., Conversion of coffee residue waste and Eucalyptus globulus leaf extract into an alternative solid fuel. Energy Sources, Part A: Recovery, Utilization, and Environmental Effects, 40, pp. 780-786, 2018. https://doi.org/10.1080/ 15567036.2018.1463309. 
[10] Ushakov, D.E., Karelin, D.V., Bychkov, A.L., Korobeinichev, O.P. \& Shmakov, A.G., Preparation of fuel briquettes from plant biomass. Solid Fuel Chemistry, 51, pp. 238242, 2017. https://doi.org/10.3103/S0361521917040103.

[11] Shuma, M.R., Madyira, D.M. \& Oosthuizen, G.A., Combustion behavior of loose biomass briquettes resulting from agricultural and forestry residues. International Conference on the Domestic Use of Energy (DUE). IEEE 2017, pp. 38-44, 2017. https://doi.org/10.23919/DUE.2017.7931822.

[12] Malak, K. et. al., Green coal: A new energy source from leaves. Energy Procedia, 100, pp. 484-491, 2016. https://doi.org/10.1016/j.egypro.2016.10.207.

[13] Jittabut, P., Physical and thermal properties of briquette fuels from rice straw and sugarcane leaves by mixing molasses. Energy Procedia, 79, pp. 2-9, 2015. https://doi.org/10.1016/j.egypro.2015.11.452.

[14] Nurdin, H., Hasanuddin, D., Setiadhi, Y. \& Saddikin, M., Calorific value of tibarau cane bio-briquette. Journal of Physics: Conference Series, 1317, 2019. https://doi.org/ 10.1088/1742-6596/1317/1/012110.

[15] Orfao, J.J.M., Antunes, F.J.A. \& Figueiredo, J.L., Pyrolysis kinetics of lignocellulosic materials-three independent reactions model. Fuel, 78, pp. 349-358, 1999.

[16] Van Loo, S. \& Koppejan, J., (eds), Biomass Combustion \& Co-firing, Earthscan: London, 2008.

[17] Raveendran, K., Ganesh, A. \& Khilar, K.C., Influence of mineral matter on biomass pyrolysis characteristics. Fuel, 74, pp. 1812-1822, 1995. https://doi.org/10.1016/0016-2361(95)80013-8.

[18] Parathasarathy, P. \& Narayanan, S.K., Determination of kinetic parameters of biomass samples using thermogravimetric analysis. Environmental Progress \& Sustainable Energy, 33, pp. 256-266, 2014.

[19] Chandrasekaran, A., Sethumadhavan, R. \& Senthilmurugan, S., Determination of kinetic parameters in the pyrolysis operation and thermal behavior of prosopis juliflora using thermogravimetric analysis. Bioresource Technology, 233, pp. 413-422, 2017. https://doi.org/10.1016/j.biortech.2017.02.119.

[20] Sun, Z. et al., Thermogravimetric and kinetics investigation of pine wood pyrolysis catalyzed with alkali-treated CaO/ZSM-5. Energy Conversion and Management, 146, pp. 182-194, 2017. https://doi.org/10.1016/j.enconman.2017.04.104.

[21] $\mathrm{Gu}, \mathrm{L}$. et al., Persulfate oxidation assisted hydrochar production from Platanus Orientalis leaves: Physicochemical and combustion characteristics. Bioresource Technology, 244, pp. 517-524, 2017. https://doi.org/10.1016/j.biortech.2017.07.173.

[22] Long, Y. et al., TG-FTIR analysis of pyrolusite reduction by major biomass components. Chinese Journal of Chemical Engineering, 23, pp. 1691-1697, 2015. https://doi.org/10.1016/j.cjche.2015.08.028.

[23] Garcia-Maraver, A., Salvachúa. D., Martínez, M.J., Diaz, L.F. \& Zamorano, M., Analysis of the relation between the cellulose, hemicellulose and lignin content and the thermal behavior of residual biomass from olive trees. Waste Management, 33, pp. 2245-2249, 2013. https://doi.org/10.1016/j.wasman.2013.07.01.

[24] Mishra, R.K. \& Mohanty, K., Pyrolysis kinetics and thermal behavior of waste sawdust biomass using thermogravimetric analysis. Bioresource Technology, 251, pp. 63-74, 2018. https://doi.org/10.1016/j.biortech.2017.12.029.

[25] Yao, X., Kaili, X., Fang, Y. \& Liang, Y., The influence of ashing temperature on ash fouling and slagging characteristics during combustion of biomass fuels. Bioresources, 12, pp. 1593-1610, 2017. http://dx.doi.org/10.15376/biores.12.1.1593-1610. 
[26] EN 13240, Room heaters fired by solid fuel - Requirements and test methods. Czech Office for Standards Metrology and Testing: Prague, 2002.

[27] Commission Regulation (EU) 2015/1185 of 24 April 2015 implementing Directive 2009/125/EC of the European Parliament and of the Council with regard to ecodesign requirements for solid fuel local space heaters. 